\title{
The Unfulfillable Promise of Meritocracy: Three Lessons and their Implications for Justice in Education
}

\author{
Jonathan J.B. Mijs \\ Harvard University
}

This is a pre-print of a paper published in Social Justice Research 29(1): 14-34.

DOI: $\underline{10.1007 / \mathrm{s} 11211-014-0228-0 .}$.

\begin{abstract}
This paper draws on a literature in sociology, psychology and economics that has extensively documented the unfulfilled promise of meritocracy in education. I argue that the lesson learned from this literature is threefold: 1) educational institutions in practice significantly distort the ideal meritocratic process; 2) opportunities for merit are themselves determined by nonmeritocratic factors; 3 ) any definition of merit must favor some groups in society while putting others at a disadvantage. Taken together these conclusions give reason to understand meritocracy not just as an unfulfilled promise, but as an unfulfillable promise. Having problematized meritocracy as an ideal worth striving for, I argue that the pervasiveness of meritocratic policies in education threatens to crowd out need and equality as principles of justice. As such it may pose a barrier rather than a route to equality of opportunity. Furthermore, meritocratic discourse legitimates societal inequalities as justly deserved such as when misfortune is understood as personal failure. The paper concludes by setting a research agenda that asks how citizens come to hold meritocratic beliefs; addresses the persistence of (unintended) meritocratic imperfections in schools; analyzes the construction of a legitimizing discourse in educational policy; and investigates how education selects and labels winners and losers.
\end{abstract}




\section{INTRODUCTION}

mer $\cdot i \cdot$ toc $\cdot r a \cdot c y$

1. An elite group of people whose progress is based on ability and talent rather than on class privilege or wealth.

2. A system in which such persons are rewarded and advanced: The dean believes the educational system should be a meritocracy.

3. Leadership by able and talented persons.

Evaluating the definition of meritocracy, one is inclined to nod in silent agreement. At face value it is a workable and just principle for allocating reward and societal advancement. In the 56 years since Michael Young (1958) coined the term in his The Rise of Meritocracy (hereafter TRoM), the principle has found abundant support and now settles in a comfortable position in education, economics, sports and other spheres of life. It underlies the prevalent belief that success in school and work is and ought to be determined by one's talents and efforts (Kluegel \& Smith, 1986; McCall, 2013). This is a reassuring thought for those with talent, and perhaps a comforting one for those without — at least they were given a fair chance (McCoy, Wellman, Cosley, Saslow, \& Epel, 2013).

This article however takes a critical approach to the concept of meritocracy. It problematizes the idea of meritocracy and lays bare the discomforts hidden within its principles and practices. Extant empirical research on meritocracy in education has focused on inequality of opportunity (Arrow, Bowles, \& Durlauf, 2000); social (im)mobility (Dench, 2006); or reproductive processes in schools (Calarco, 2014; Goldthorpe \& Jackson, 2008). Such studies 
point to meritocratic imperfections and expose non-meritocratic elements within the practice of meritocratic selection. Taken together this body of work has shown the unfulfilled promise of meritocracy. Another branch of work has analyzed the principles and philosophical roots of meritocracy (Allen, 2011; Panayotakis, 2014; Saunders, 2006). This paper is an attempt to bridge these literatures by bringing empirical findings to bear on a careful scrutiny of the notion of meritocracy. To that end, I offer a brief history of the term meritocracy and its reception in academia and beyond; a re-examination of the empirical literature on meritocracy in education; a discussion of the implications of what research has taught us; and a look at the future of meritocracy research.

In what follows I will show, first, how Young's TRoM has been welcomed in the realm of policy and research as an appraisal rather than a dystopia of meritocracy, and how this has led to overlooking the problematic nature of the notion and its practical manifestations. I will suggest that the positive reception should be seen in light of the notion's functional character and the legitimation it provides to social inequality. By reference to the social science literature on educational inequality, I will problematize the notion of meritocracy by showing that merit is itself determined by non-meritocratic factors. Moreover, I will show that the practical setup and organization of education introduces serious distortion to meritocratic ideals. Further, I will argue that any particular definition of merit is a construction that must serve some groups of people, while disadvantaging others. My central thesis: meritocracy is not just an unfulfilled promise; meritocracy is an unfulfillable promise.

Having problematized the notion of meritocracy as an ideal worth striving for, I then discuss the pervasiveness of meritocracy in educational policy, which threatens to crowd out need and equality as principles of justice, to the detriment of equality of opportunity. I conclude 
by proposing a research agenda on meritocracy in education. I suggest that future research asks how citizens come to hold meritocratic beliefs; addresses the persistence of meritocratic imperfections; scrutinizes the construction of a legitimizing discourse in schools and in educational policy; and that it be more open to analyze how winners and losers are selected and so-labeled.

\section{THE RECEPTION OF MERITOCRACY}

The concept of meritocracy can be broken down into three constituent elements: i) careers open to talents; ii) educational opportunity matched to natural ability; iii) achievement as the basis for social inequality in industrial society (Goldthorpe, 1996, pp. 255-256; Yair, 2007). The first element of meritocracy reflects the call to open up positions to those who display competence, rather than award positions through nepotism, bribery and the like-a call that was heard in the French Revolution and has been a hallmark of modernity ever since.

The second element refers to the process of testing and selection that emerged in tandem with systems of mass education in the $19^{\text {th }}$ century across Europe and the US (Raftery \& Hout, 1993), in order to ensure that those children who show the greatest potential get the best possible education so that 'talent does not go to waste.' This wasted talent argument was felt particularly strongly in the cold war, on both sides of the iron curtain. A good illustration of this concern is Stevenson \& Stigler's (1994) series of studies of Japan and Taiwan in the 70s and 80s, and it has in recent times re-entered both American policy (e.g., the 'No Child Left Behind' act of 2001) and European Union policy (e.g., the 'Lisbon Agenda' of 2000).

The third element of meritocracy corresponds to the functionalist idea that ascription 
needs to be replaced by achievement: for society to perform most efficiently, differences in achievement should lead to different rewards. Davis and Moore, early representatives of this tradition, formulate this principle as follows: "Social inequality is an unconsciously evolved device by which societies insure that the most important positions are conscientiously filled by the most qualified persons" (Davis \& Moore, 1945, p. 243). Meritocracy thus provides a basis for the allocation of reward; namely, achievement. Achievement, furthermore, should be a function of natural ability and effort. Young, in TRoM, expressed this idea in the formula M=I $+\mathrm{E}$, where $\mathrm{M}$ is merit, I is natural endowments (in particular IQ) and $\mathrm{E}$ is effort.

It should be noted that the word meritocracy, and its formula, was proposed by Young in a dystopian work of fiction. Its reception however has not always been as critical of the principles of meritocracy as Young was (as he himself observed and lamented in Young [1994], and in Young [2001] where he directly addresses then-prime minister Tony Blair). Willetts makes this point in reflecting on TRoM: "Although some people in America have read it as a paean of praise for meritocracy, it is really a deeply ironic critique of the whole idea. [Young] argues that to lose out in a society because of bad luck is painful enough, but to lose out because you are assessed as being without merit is far worse" (Willetts, 2006, p. 237). Goldthorpe in similar fashion states, "it is notable that in the liberal - and especially the American liberal reception of Young's work, its satirical and critical quality was in fact largely overlooked or, at all events, discounted (...) American enthusiasm for meritocracy appeared largely to derive from its legitimatory potential. It allowed an additional, moral gloss to be given to arguments that sought to justify the prevailing form of social inequality (or something close to this) purely in terms of its functional efficiency" (Goldthorpe, 1996, pp. 279-280).

This is not to say that the reception of meritocracy has been completely uncritical. As I 
will describe in the next section, discussion and reflection in the scientific community has been critical and pervasive. None of these criticisms have however kept educators, employers or politicians from adopting the principle of meritocracy as the primary principle guiding the selection of candidates, allocation of reward, and, most importantly, legitimation of difference. This I suggest has to do with the fact that meritocracy serves two important purposes for policymakers. First, it provides a moral basis for the allocation of scarce goods such as monetary reward, status, or to put it more broadly 'societal success.' Miller illustrates this point in writing of instrumental association: "Each person comes to the association as a free agent with a set of skills and talents that he deploys to advance its goals. Justice is done when he receives back by way of reward an equivalent to the contribution he makes. A person's deserts, in other words, are fixed by the aims and purposes of the association to which she belongs; these provide the measuring rod in terms of which relative contributions can be judged" (Miller, 1999, p. 28).

In other words, given clear objectives, meritocracy provides a principle of justice for the allocation of reward: whoever performs best justly deserves the highest reward. From this example follows the second purpose served by meritocracy: to stimulate effort. Given that desert is a function of effort and ability, one is incentivized to try hard. While this seems a trivial point, its relevance becomes clear in light of the principles which meritocracy opposes. Ascription, for instance, implies that reward is allocated independent of one's achievement-i.e. by birth. Likewise, the stronger the practice of nepotism and bribery, the less likely people are to feel motivated to spend effort in trying to attain the impossible (Eccles \& Wigfield, 2002; Weiner, 1972). This second purpose of meritocracy — to incentivize effort—reflects the functionalist or utilitarian element of meritocracy. It is the combination of these two purposes that defines meritocracy's appeal to policymakers: it legitimates difference, stimulates effort, and in doing so 
optimizes the allocation of reward.

\section{LITERATURE: THREE LESSONS LEARNED}

A long line of research has critiqued the functionalist view of educational practices. Scholars have addressed inequalities in access to education, and have described how the particular arrangement of educational systems de-facto function, if not directly serve, to further the interests of some groups in society over those of others (Bourdieu \& Passeron, 1977; Breen \& Jonsson, 2005; and for a review of recent work on cultural processes of exclusion and legitimation, see Lamont, Beljean, \& Clair, 2014; Stephens, Markus, \& Phillips, 2014). In particular, studies have expressed concerns with the operation of institutions; have unmasked them as not purely 'functional,' and have as such pointed to meritocratic imperfections, and exposed non-meritocratic elements within the practice of meritocratic selection. Taken together these studies have shown the unfulfilled promise of meritocracy. ${ }^{1}$

The story that these studies tell is well-known, and has come to motivate ongoing efforts by scholars and policy makers to 'equalize opportunities' (Liu, 2011), to build more 'inclusive schools' (Halvorsen \& Neary, 2001), and to 'close the achievement gap' (Noguera \& Wing, 2008). A close reading of extant research however gives good reason to hold our enthusiasm and to question how successful meritocratic policies could ever be given the problems inherent in the meritocratic notion itself. The following revisits and re-examines what we have come to know about meritocracy in order to present three lessons that directly bear on this question. Together, I

\footnotetext{
${ }^{1}$ In fact the entire oeuvre of the most-widely cited social scientist, Pierre Bourdieu, can be read as describing and confronting the broken promise of the French Revolution, its meritocratic ideals in particular, as nepotism and aristocratic remnants of the Ancien Régime linger on today (Yair, 2007, 2008).
} 
will argue, these lessons show that meritocracy is not just an unfulfilled promise, but that it is an unfulfillable promise.

\section{Lesson 1: Educational institutions distort the meritocratic process}

No school is the same; in fact most school systems are marked by large differences in quality of instruction and in the population of students attending a school. While some of these differences are random, there are strong and highly visible patterns of difference between public and private schools and along the lines of school segregation. Even within integrated public schools however the educational experience of students varies as a result of (between-school) educational tracking in ability groups and (within-school) streaming into vocationally and academically-oriented classes (LeTendre, Hofer, \& Shimizu, 2003). Ability grouping directly impinges on the quality of class instruction and the beneficial or harmful influence of the peer group a student is embedded in. It affects drop-out rates and access to higher education, and is indirectly associated with teacher quality, school violence, and anxiety (Arum \& Beattie, 1999; Oakes, 2005; Van de Werfhorst \& Mijs, 2010).

The process that allocates students is thus enormously consequential for the kind and quality of education they receive and, ultimately, for their chances of societal success. Research shows that even where placement and selection processes are meritocratically set up (e.g., based solely on test scores), a student's ethnicity and social class bears heavily on what track or stream a student ends up in: children of more affluent and well-educated parents are significantly more likely to end up in higher standard classrooms than are children of low-educated parents with equivalent academic talents. The same pattern arises in major educational transitions, such as 
finding a good pre-school (Lareau, 2000), choosing whether or not to stay in school beyond compulsory education (Kalmijn \& Kraaykamp, 2003) and getting into college (Espenshade \& Radford, 2009). Lucas (2001) shows how even when educational opportunities expand and schools become more inclusive, a student's social class background remains an important predictor for the quality and level of education (s)he gets within a tracked school system.

Part of these processes are driven by teacher bias, stereotype threat (Steele, 2011; Walton, Spencer, \& Erman, 2013) and by the design of examinations and selection procedures (Fischer et al., 1996). Research suggests however that parents play such an important role in these processes that even in the absence of bias, similarly talented children from different social backgrounds would end up with different quality education (Jackson, Erikson, Goldthorpe, \& Yaish, 2007; Kloosterman, Ruiter, De Graaf, \& Kraaykamp, 2009). The primary and secondary effects of social class literature describes parents' twofold role in shaping their children's education: directly, by endowing them with the genetic disposition, upbringing and social context that shapes a child's chances to do well in school (see next section), and indirectly, through the motivation, support and pressure they do or do not provide their child whenever (s)he is faced with an educational choice, e.g., to take AP classes or not, to stay in school beyond compulsory education, or to seek enrollment in a two or in a four year college (Jackson, 2013).

\section{Lesson 2: Opportunities for merit are undeserved}

Underlying the fact that parents weigh in on the educational selection process, as described in the preceding, is a problem associated with the very principle of meritocratic selection. Merit implies having to deserve one's achievements. Meritocracy accepts as just 
grounds for merit, a person's efforts as well as ability. For instance, a scholar who submits the best manuscript deserves the prestigious publication; the athlete who crosses the finish line ahead of her competition, deserves the gold medal. But does a student who studies hard deserve a good grade? Not necessarily so. Her efforts may have been great, but not good enough. Likewise, a fellow student who is brighter, yet made little effort preparing, may from a meritocratic point of view deserve a higher grade when her test score is greater.

Bearing heavily on these questions is the unequal allocation of natural endowments: natural ability, IQ, physical condition, attractiveness and other well-identified factors for success in important spheres of life are not distributed equally by the lottery of birth (Fischer et al., 1996). More to the point: the distribution of children's talents is not based on meritocratic principles; the meritocratic race starts from unequal and non-meritocratic starting positions. In accepting merit as the basis on which to allocate reward, we must thus violate the very justness of that criterion.

\section{Lesson 3: There is no neutral definition of 'merit'}

The research discussed so far suggests that meritocratic selection carries within it nonmeritocratic elements: an important source for merit is undeserved but decided instead by the lottery of birth; and the assessment of merit is distorted through the institutions that allocate

reward, as well as through the influence of social class. A final dimension to consider is how the standards for merit are set.

Table 1 describes sets of meritocratic traits across societies and over time. Manliness, aggression, asceticism and (bi)sexuality, for instance, were considered important traits for men to 
have in Sparta, 400 B.C., and display of such traits was rewarded with social status (De Botton, 2005). In Western Europe anno 479, in contrast, pacifism, vegetarianism and asexuality were considered meritocratic traits (ibid.). Similarly changes in meritocratic traits over time are described with regard to the rise of court society (Elias, 1939), in the evaluation of American social science and humanities scholarship (Tsay, Lamont, Abbott, \& Guetzkow, 2003), as well as between men and women today (Prentice \& Carranza, 2002). These studies serve to make the point that what constitutes merit is historically shaped and institutionally-specific (Baez, 2006; Liu, 2011; Rhoads, Saenz, \& Carducci, 2005). How merit is constructed will be illustrated through a closer examination of one of the works referenced in Table 1.

[Table 1 about here]

Karabel's (2005) The Chosen shows how the definition of merit at Harvard, Yale and Princeton developed throughout the twentieth century as a continuing adaptation to external forces, considered by these institutions as threats to their integrity, status, and prestige. ${ }^{2}$ In response to these perceived threats, the leaders of these universities tweaked and changed their admission criteria — the definition of merit— so as to be able to legitimately exclude unwanted outsiders: Catholics, (Eastern-European) Jews, non-whites and women. Karabel spent years in the archives digging up minutes that described in detail the meetings at which such criteria were shaped and refined so as to attain the desirable outcome: keeping these top universities the exclusive privilege of 'our kind of people.' His account of university chancellors defining merit

\footnotetext{
${ }^{2}$ Liu's (2011) account of changing admission policies at the University of California similarly describes how merit is redefined as a response to external forces, in this case the triad of state, courts and public.
} 
illustrates a broader point: "[T]hose who are able to define "merit" will almost invariably possess more of it, and those with greater resources — cultural, economic, and social—will generally be able to ensure that the educational system will deem their children more meritorious" (Karabel 2005: 550).

While Ivy League universities have become more inclusive over the years, in particular with regard to racial diversity (Bowen, Bok, \& Shulman, 1998; but see Hoxby \& Avery, 2013; Michaels, 2006), the socio-economically privileged are still wildly over-represented. For instance, of Harvard University’s freshmen today 15 percent reports an annual household income of $\$ 250,000$ to $\$ 500,000$; another 14 percent comes from a family making over $\$ 500,000$ a year (Anasu \& Ledecky, 2013). This puts these students at the top 5 and top 1 percent of the US income distribution, respectively, meaning that children of the (super) wealthy go to Harvard at a rate of 3 and 14 times as high as one would expect if family income and admission into Harvard were unrelated.

Two recent studies by Castilla show that decision makers need not have bad intentions for non-meritocratic practices to persist. Castilla examines a company that adopted an explicit meritocratic policy to advance equal rights for women and minorities (Castilla, 2008). The adoption of that policy however introduced bias in performance evaluation and in the link between these evaluations and outcomes such as wage setting and promotion decisions. Castilla \& Benard (2010) confirm this finding, and adopt a series of experiments to show the causal link between meritocratic policy and a (non-meritocratic) gender bias: paradoxically, in explicitly meritocratic settings, persons in positions of power may feel more comfortable to express prejudice toward minority groups.

These studies show the incorporation of (meritocratic) practices as forms of symbolic 
'organizational myths' (Meyer \& Rowan, 1977) which instead of advance, may in fact hamper meritocratic selection (Dobbin, 2009). A further illustration is Khan's (2010) ethnography of the New Hampshire boarding school St. Paul's which shows that organizations such as elite schools do not just recognize and cultivate a person's talents, but in important ways, make merit. Khan describes how these students are taught to act meritoriously and to expect success, and how colleges perceive and reward these acts accordingly. Khan invokes Durkheim's (1912) concept of consecration to make sense of his observations: "I am firmly telling a Durkheimian story of how elite culture works through the elevation of a small group not by their individual characters but by a social process of schooling, Students experience consecration each day on campus through the teachers that give themselves to the students. These privileged students are made into elites by the interactions that consecrate them, by the consistent, generous feedings they receive of their own capacity and promise” (Khan, 2010, p. 162).

Having problematized the notion of meritocracy and the definition of merit allows for a consideration of meritocracy not just as an ideal worth striving for. In the next two sections I argue that meritocratic policies may have detrimental effects. First, the meritocratic norm blames the victim. Second, merit threatens to crowd 'need' and 'equality' from the realm of educational policy, with grave consequences for equality of opportunity.

\section{IMPLICATIONS}

\section{Blaming the victim}

The other side of the meritocratic medal, earned by those who work hard and do well, reveals the credo that the individuals, not society is to blame for his or her failings. Thus, 
whereas we have learnt that, to use C. Wright Mills' typology, 'private troubles' often in fact reflect 'public issues,' meritocratic policies lead us to forget this important lesson: "When, in a city of 100,000 , only one man is unemployed, that is his personal trouble, and for its relief we properly look to the character of the man, his skills, and his immediate opportunities. But when in a nation of 50 million employees, 15 million men are unemployed, that is an issue, and we may not hope to find its solution within the range of opportunities open to any one individual" (Mills, 1959, p. 9 emphasis added).

Man's dependence on the individual economic pursuit of butchers and bakers, as Adam Smith (1778) described it in his The Wealth of Nations, has in the last century seen a global expansion. Modern man has only a vague notion of who his 'butchers and bakers' are, less so of where they might be located or how exactly one's daily life is dependent on them. Financial institutions, interwoven into globe-spanning networks, provide the backbone for many of our daily expenditures. Or fail to do so, as we have experienced in the subprime mortgage crisis of the mid-2000s. Still, international exchange and supranational agreements, on trade, energy, etc., set the price for most of the products and services we use.

These global processes profoundly affect our daily lives. Beck (1992) describes these effects in his The Risk Society: factors beyond our control have immediate and often irreversible impact on our lives. The paradox is that while our grasp of control is slipping, the stress on personal responsibility dramatically increased. In uncritically taking meritocratic norms for meritocratic practice, we take the risk of blaming the victim. This has been topic of research in the belief in a just world tradition which describes a human tendency to accept inequalities as deserved; this allows people to maintain their belief that they live in a fair world rather than having to address those inequities (Jost, Banaji, \& Nosek, 2004; Lerner, 1980). Meritocracy 
justifies this inclination and expands it to national level policy.

Meritocratic policy fosters the illusion of 'manageable success' and adds insult to injury by providing the moral legitimation of failure: "Consequently, social crisis phenomena such as structural unemployment can be shifted as a burden of risk onto the shoulders of individuals. Social problems can be directly turned into psychological dispositions: into guilt feelings, anxieties, conflicts and neuroses. Paradoxically enough, a new immediacy develops in the relationship between the individual and society, an immediacy of disorder such that social crises appear as individual and are no longer - or only very indirectly - perceived in their social dimensions" (Beck \& Beck-Gersheim, 2002, p. 24).

Carrying the banner for meritocracy, we accept its standards as the societal standards on which to judge people's actions. The strongest athletes are champions, the best performing company is a best practice, and the toddler who received the first prize in his school's drawing competition is a winner. Recognizing success necessarily implies too that we recognize failure. Meritocratic ideals imply that we look upon school dropouts or the unemployed as failures. Apart from the effect this has on a person's self-esteem, the mark of personal failure removes the right to protest, erodes the grounds for collective action, and thus effectively renders the marked immobile. As Khan writes in his book's closing paragraph, "The production of privilege will continue to reproduce inequality while implying that ours is a just world; the weapons of the weak are removed, and the blame for inequality is placed on the shoulders of those whom our democratic promise has failed" (Khan, 2010, p. 192).

\section{Crowding Out Equality and Need}


Moral philosophers distinguish as principles of justice, merit from equality and need (Nozick, 1974; Rawls, 1971; Sen, 2000). ${ }^{3}$ Political ideologies have placed emphasis on different principles, and we all know the horrors of the extremes - e.g., that of 'equality' in communism. Modern democracies tend to hold in high regard all of these principles of justice. The extent to which a particular principle is held to be important is often related to the domain individuals interact in.

Equality, for instance, serves as the dominant principle in the political sphere (e.g., voting rights are provided equally to all citizens, and each vote counts equally). In the public sphere, people expect to be treated equally by civil servants, as anonymous 'cases' in the bureaucratic system. Likewise, we respect the basic needs of citizens as human rights. States have welfare provisions to guarantee that all citizens can find shelter, food and medical attention when they need it. The Universal Declaration of Human Rights (article 26) makes explicit reference to these rights as well as to the right to education.

Miller develops this moral logic in his Principles of Social Justice. Instead of arguing that one principle is dominant over the others, Miller proposes that the mode of relationship should determine the principle it be governed by. He distinguishes three ideal types. The first is solidaristic community, where people "who see themselves as bound together by common beliefs or culture as well as by kinship or acquaintance" (Miller, 1999, p. 26) come together. The second mode of relationship is instrumental association where people interact in order to accomplish things that can best be done in collaboration with others. Economic relations are the 'paradigm case': people relate to one another as buyer and seller of goods and services. Third comes

\footnotetext{
${ }^{3}$ Deutsch, in a long line of research, empirically studied how different justice principles arise in group interactions as a result of the type of social relations that marks the group, i.e. cooperative or competitive (Deutsch, 1985). The next section, pp. 22-24, suggests an alternative approach to a similar question: where do meritocratic beliefs come from?
} 
citizenship, as Miller explains: "Anyone who is a full member of [a modern liberal democracy] is understood to be the bearer of a set of rights and obligations that together define the status of citizen" (Miller, 1999, p. 30). Moreover, he stresses that citizenship entails both its legal status and a common social and political status. Miller argues that instrumental association should be governed by the principle of desert, solidaristic community by need and citizenship by equality. Stressing the ideal-typical nature of his argument, Miller discusses the problems associated with assigning actual domains of action to any particular mode of relationship. Take education: "From an instrumental point of view, education is a practice within which children with different talents work to acquire new concrete skills that they then carry forward into the labor market; for the final distribution of occupational rewards to correspond to desert, each child must have access to educational resources according to his or her demonstrated capacity to make use of them. If we start from citizenship, by contrast, education matters as the place where children acquire the capacities that enable them to function as competent citizens (...) in the sense that they learn to cooperate with others, to engage in political discourse, and generally to participate in the various spheres of social life" (Miller, 1999, pp. 37-38).

Contrary to these philosophical considerations however a preoccupation with meritocracy in educational policymaking risks crowding out equality and need. European Union debates on how to stimulate 'excellence,' cater for 'honor's students,' or win the 'battle for brains,' have one thing in common: a disregard of the moral principles of equality and need, for all these policy issues focus exhaustively on merit. US policy such as 'No Child Left Behind,' may by its title signal more consideration to equality, but looking beyond the name it is evident that the justification for such a policy is to prevent 'talent go to waste.' Such considerations become most evident in policy makers' responses to internationally-comparative rankings of schools and 
countries; "nothing seems to spell doom in American education quite like internationally inadequate mathematics and science education. In fact, this is probably the case in most countries” (Baker \& LeTendre 2005, p. 154). Consider President Obama's reaction to the Program for International Student Assessment (PISA) 2010 study results: “ 'Fifty years later, our generation's Sputnik moment is back,' Mr. Obama said. With billions of people in India and China 'suddenly plugged into the world economy,' he said, nations with the most educated workers will prevail. 'As it stands right now," he said, 'America is in danger of falling behind' " (Dillon, 2010).

As is true for EU educational policy, functionalist considerations underlie American educational policy. It serves to legitimate difference, stimulate effort, and in doing so optimize the allocation of reward. Analyses of educational policy documents of the Organization for Economic Co-operation and Development (OECD) similarly reveal a very narrow conception of fairness in education rooted in economic rationality, which ignores or gives only cursory attention to equality and need (Bøyum, 2014; Rizvi, 2013; Savage, Sellar, \& Gorur, 2013).

The question that is rarely posed is why does a more apt student require a better education. Why does aptitude guide the allocation of resources? An alternative to extant 'meritocratic' education would be to compensate lower aptitude with a more sizeable investment of educational resources (principle of need), or to offer students the same educational opportunities independent of their abilities (principle of equality). Much of contemporary thinking is explained by the metaphor of investment (Becker, 1964, 1993; Mincer, 1958), which leads one to consider, if only implicitly, the expected returns on investment. Such reasoning of course favors the allocation of resources to those who show the greatest potential. Why this is more just than compensating the less apt student, or treating both equally, is rarely discussed if at 
all recognized as a legitimate point for discussion.

An exclusive focus on merit in education reduces schools to a mere training ground for the labor market. It leads to disregarding the important role of education in building character and citizenship. As Rawls has it, "important is the role of education in enabling a person to enjoy the culture of his society and to take part in its affairs, and in this way to provide for each individual a secure sense of his own worth" (Rawls, 1971, p. 87). Need, too, is an important criterion that applies to education for in order to provide for one's basic needs in modern society, one cannot realistically do without education - in the strict economic sense as well as in understanding the role education plays in social and political emancipation. In this light, entry into education as well as access to further education is to be unrestricted if we care to give individual students a fair opportunity to be able to provide for themselves in adulthood. But how to reconcile these various principles of justice in the practice of educational selection?

Walzer's (1983) elegant way out is to argue that a second and third principle of justice can be applied in coherence with the first. Applying this to education, he argues that in understanding the role that education plays in promoting citizenship, it is essential to have some basic level of unrestricted and undifferentiated, comprehensive, and compulsory education for all. Furthermore, in recognizing the importance of education as a means for people to provide for their basic needs, we would do well by promoting that individuals have access to any particular form and degree of education that sufficiently equips them to do so. Finally, education beyond a minimum level as defined by the principles of need and equality could then be made available to individuals according to their merit.

There are two additional reasons not to disregard equality as a principle of justice. One has to do with equality of opportunity. The principle of equal opportunity, as we have seen, is 
consistent with the idea of meritocracy, yet not with its practice. Recall that meritocratic selection should provide for each a chance to deserve their reward. In practice however, the unequal distribution of endowments, the influence of family background, as well as institutional distortions, produce unequal starting points and opportunities. This means that equality of opportunity is not served by meritocratic practice. In order to restore the principle, we would need more equality as such-more equal outcomes. For equality of opportunity to be greater, that is, starting positions need to be more equal. Hence, either the factors that influence starting positions must be minimized or they must be equalized. The first implies 'fixing' institutions so that they no longer affect people differently, preventing parents from interfering in their children's education, preventing people from marrying homogamously, and of course ensuring that people be unaffected by things beyond their control. While some steps could be made in this direction by means of compulsory pre-schools and the expansion of comprehensive education, the examples illustrate the very unattainability of such an approach.

Another approach is more feasible. It implies not that the effects of the factors of influence be minimized, but that they be equalized. This idea approaches what Rawls had in mind by his redress principle: "[S]ince inequalities of birth and natural endowment are undeserved, these inequalities are to be somehow compensated for. Thus (...) in order to treat all persons equally, to provide genuine equality of opportunity, society must give more attention to those with fewer native assets and to those born into the less favorable social positions. The idea is to redress the bias of contingencies in the direction of equality" (Rawls, 1971, p. 86).

This approach thus entails instituting compensatory mechanisms to approximate equality, in order to increase equality of opportunity. One example has already been provided: pre-schools that cater to the socially disadvantaged can serve to reduce inequality. Comprehensive schooling, 
to take another, helps socialize the advantaged and disadvantaged together so that the latter share the benefits of the former's (parental) resources. Furthermore, it increases the chance of intergroup relation(ship)s and equalizes the effects of assortative mating. Ultimately, what should be recognized is that perfect equality of opportunity does not exist without equality of outcome. Hence truly 'meritocratic' education policy cannot deal with merit without addressing equality.

\section{CONCLUSION: A RESEARCH AGENDA}

In this paper, I have argued that merit bears within it a hidden discomfort. While meritocracy holds that merit is a function of effort and ability, much more in fact influences one's chances of success. The contingencies of modern life pose sizeable obstacles that effort and ability cannot always overcome. Furthermore, societal institutions seriously distort the meritocratic process in increasing inequalities rather than providing the level playing field that policy makers want them to establish. At the same time, meritocracy stresses our personal responsibility to work hard in order to make our own future. Promoting the illusion of $\mathrm{M}=\mathrm{I}+\mathrm{E}$, then, implies not only that people are given false hope, but legitimates societal inequalities as justly deserved, and misfortune becomes personal failure.

I argued too that people have unequal starting positions and that these positions are undeserved. It matters, that is, which family you are born into, as well as how attractive, bright and strong you are. None of these endowments however are meritocratically deserved. Understanding their pivotal role in meritocratic selection thus implies that we recognize that meritocracy in practice violates its own merit principle. I argued, finally, that educational policy and discourse informed by meritocracy may neglect, at great costs, the principles of need and 
equality. Moreover, disregarding equality implies abandoning our pursuit for equality of opportunity.

While we have learned, and continue to learn more about meritocratic imperfections, this article suggests that a complete understanding of meritocracy requires us to recognize the problems inherent in the notion of meritocracy. This concern informs a research agenda that incorporates four strands.

\section{Where do meritocratic beliefs come from?}

Whereas the majority of citizens across countries hold meritocratic beliefs, there are strong patterns of variation in the strength of those beliefs. Figure 1 shows meritocratic and nonmeritocratic beliefs for citizens of the 38 countries included in the International Social Survey Programme (ISSP Research Group, 2012).

[Figure 1 about here]

In addition to variation between countries of the world (M. L. Smith \& Matějů, 2012; Telles \& Bailey, 2013), studies have described patterns of variation within countries along the lines of social class, income, gender, race and education, among other variables (Grayman \& Godfrey, 2013; Hunt, 2007; Kluegel \& Smith, 1986).

Scholars have struggled to explain these patterns of variation. Researchers in the belief in a just world tradition have described meritocratic beliefs from a human tendency to maintain a belief that the world they live in is fair and does not require inequalities to be addressed (Jost et 
al., 2004; Lerner, 1980). Along the same lines, scholars have posited that meritocratic beliefs serve individual or group interests, i.e. those of successful societal elites or groups that have an interest in maintaining their advantages more generally. These explanations however fail to account for the observation that 1) many people in fact do not think they live in a just world (Delhey \& Dragolov, 2014; McCall, 2013), and, often, 2) meritocratic beliefs go against a person's interests, as when underprivileged societal groups explain inequalities as resulting from differences in effort and ambition (Jost \& Banaji, 1994; Kay et al., 2009; McCoy \& Major, 2007) or when the privileged justify their own privilege (Croll, 2013).

Other scholars look at cultural factors, such as citizens' socialization into their national ideology — e.g., the American dream (Hochschild, 1996) — for the source of stratification beliefs (Choi, Nisbett, \& Norenzayan, 1999; Heine \& Buchtel, 2009; Huber \& Form, 1973). Their explanation builds on findings of large 'cultural differences' between citizens of the world—e.g., Japanese citizens hold vastly different stratification beliefs from Americans, who in turn differ strongly from the Danish. This cannot however account for similarly large differences within countries and cultures, along the lines of social class, gender, race, and educational attainment, as reported above.

Rather than try to explain meritocratic beliefs in terms of (universal) human psychology, research might benefit from taking more seriously the different socialization trajectories and institutional settings that citizens are exposed to during upbringing and beyond. A possible starting point is suggested by Lareau (2011) who shows the lasting impact of different patterns of upbringing on young people's sense of self and other, their aspirations and expectations and eventual societal success. 


\section{How do meritocratic imperfections persist?}

Second, we need to have a better understanding of the persistence of meritocratic imperfections. We have much to gain from studies like that of Castilla (Castilla, 2008; Castilla \& Benard, 2010) which have investigated in detail how the particular institutionalization of meritocratic policy can lead to unforeseen and unwarranted outcomes. Such research needs to take seriously the unfulfillable nature of the meritocratic promise, lest it be blind to the undeserved factors that enter the meritocratic race, and the subtle cultural processes (Lamont et al., 2014) that exclude some (category of) people and legitimizes that exclusion on fundamentally arbitrary and constructed grounds. A further illustration of this type of research is Stevens (2007) who describes the logic of inclusion and exclusion that admission officers (sub)consciously draw on in creating an elite university cohort of students.

\section{How is merit defined and incorporated?}

A further line of research would analyze the construction of meritocratic norms in schools' grading and selection practices, in foundations' grant awards, etc. Karabel's (2005) analysis of Ivy universities' admission criteria offers a starting point. Statements and practices that define what is 'good,' or who is 'better,' should not be taken for granted; these constructions of merit should be the explicit focus of research (Dobbin, 2009). This requires treating those distinctions and differences we are so familiar with as unfamiliar; to denaturalize 'merit,' 'success,' 'talent,' and recognize their constructed nature. As Adam Smith recognized: “The difference of natural talents in different men is, in reality, much less than we are aware of; and 
the very different genius which appears to distinguish men of different professions, when grown up to maturity, is not upon many occasions so much the cause, as the effect of the division of labor. The difference between the most dissimilar characters, between a philosopher and a common street porter, for example, seems to arise not so much from nature, as from habit, custom, and education" (A. Smith, 1776, p. 16).

An interesting further question in this light is whether meritocratic norms are a driving force behind meritocratic practices or whether they are a symptom of something else. A likely candidate is the investment logic advocated by human capital theory (Becker, 1962) in particular, and the dominance of economic calculation more generally (Centeno \& Cohen, 2012). The emphasis that policy makers place on merit, to the detriment of need and equality, suggests the dominance of a productivity logic over one of maximizing happiness, solidarity, or democratic participation — to name just a few alternatives. Alternatively, informing meritocratic practice may be the liberal individualist conception of personal responsibility, as studies suggest is particularly dominant in the U.S. (Hochschild, 1996; Shepelak, 1989; but see McCall, 2013).

\section{What are the psycho-social consequences of losing a 'meritocratic' competition?}

Last, research needs to be more open to analyze directly the formation of winners and losers through meritocratic practices. What do these experiences of winning and losing do to the individuals involved? We know of the importance of hope, and a belief in the possibility of success, in motivating individuals to commit themselves to their work, to spend effort, and resultantly, to their real chance of success (Buchmann \& Dalton, 2002; Harris, 2008; O’Connor, 1999). 
In education, the fact that many students believe they will be meritocratically assessed and rewarded could be considered a good thing; without this belief, it may be hard to work up the motivation and effort to do well in school. Similarly, some research suggests a "palliative effect" of meritocratic beliefs on those who lose out to the extent that those beliefs foster a sense of control over future outcomes (McCoy et al., 2013). The same belief, however, justifies the formation of winners and losers: if we believe the system works, then those who fail do so by their own fault. Consider the words of Friedrich Hayek in The Constitution of Liberty: "A society in which it was generally presumed that a high income was proof of merit and a low income of the lack of it, in which it was universally believed that position and remuneration corresponded to merit (...) would probably be much more unbearable to the unsuccessful ones than the one in which it was frankly recognized that there was no necessary connection between merit and success. It would probably contribute more to human happiness if, instead of trying to make remuneration correspond to merit, we made clearer how uncertain is the connection between value and merit. We are probably all much too ready to ascribe personal merit where there is, in fact, only superior value" (Hayek, 1960, pp. 98-99).

Adding to the ethical dimension of uncovering falsehood is a concern with the meritocratic illusion's effect on a person's self-perception. How does one cope, not just with being a loser, but believing that one is rightly called a loser? Moreover, what does it mean on an interactional level that the successful regard the unsuccessful as rightful losers? Coming to terms with the notion of meritocracy means taking seriously these uncomfortable questions, and designing the research to address them. 


\section{ACKNOWLEDGEMENTS}

I am much obliged to the late Daniel Bell for interrogating me on the topic of meritocracy on a cold Boston winter day three years ago, and for thereby consolidating my interest in writing this article. I thank Jason Beckfield, Thijs Bol, Filiz Garip, Sandy Jencks, Chris Marquis, Beth Truesdale, Herman van de Werfhorst, and the two anonymous reviewers for their helpful suggestions and comments on previous versions of this manuscript. Errors and conclusions are my own. 


\section{REFERENCES}

Allen, A. (2011). Michael Young's The Rise of the Meritocracy: A Philosophical Critique. British Journal of Educational Studies, 59(4), 367-382. doi:10.1080/00071005.2011.582852

Anasu, L., \& Ledecky, M. D. (2013, September 4). Freshman Survey Part II: An Uncommon App. The Harvard Crimson. Cambridge, MA.

Arrow, K. J., Bowles, S., \& Durlauf, S. N. (2000). Meritocracy and Economic Inequality. Princeton University Press.

Arum, R., \& Beattie, I. R. (1999). High School Experience and the Risk of Adult Incarceration. Criminology, 37(3), 515-540. doi:10.1111/j.1745-9125.1999.tb00495.x

Baez, B. (2006). Merit and Difference. Teachers College Record, 108(6), 996-1016.

Baker, D., \& LeTendre, G. K. (2005). National Differences, Global Similarities: World Culture and the Future of Schooling. Stanford University Press.

Becker, G. S. (1962). Investment in Human Capital: A Theoretical Analysis. Journal of Political Economy, 70 .

Becker, G. S. (1964). Human Capital: A Theoretical and Empirical Analysis, with Special Reference to Education. Chicago, IL: University of Chicago Press.

Becker, G. S. (1993). Nobel lecture: The economic way of looking at behavior. Journal of Political Economy, 385-409.

Beck, U. (1992). Risk Society: Towards a New Modernity. Thousand Oaks, CA: Sage.

Beck, U., \& Beck-Gersheim, E. (2002). Individualization: Institutionalized Individualism and Its Social and Political Consequences. Thousand Oaks, CA: Sage. 
Bourdieu, P., \& Passeron, J.-C. (1977). Reproduction in Education, Society and Culture. Thousand Oaks, CA: Sage.

Bowen, W. G., Bok, D. C., \& Shulman, J. L. (1998). The Shape of the River: Long-term Consequences of Considering Race in College and University Admissions. Princeton, NJ: Princeton University Press.

Bøyum, S. (2014). Fairness in education - a normative analysis of OECD policy documents. Journal of Education Policy, 29(6), 856-870. doi:10.1080/02680939.2014.899396

Breen, R., \& Jonsson, J. O. (2005). Inequality of Opportunity in Comparative Perspective: Recent Research on Educational Attainment and Social Mobility. Annual Review of Sociology, 31(1), 223-243.

Buchmann, C., \& Dalton, B. (2002). Interpersonal influences and educational aspirations in 12 countries: The importance of institutional context. Sociology of Education, 99-122.

Calarco, J. M. (2014). Coached for the Classroom Parents' Cultural Transmission and Children's Reproduction of Educational Inequalities. American Sociological Review, 79(5), 10151037. doi: $10.1177 / 0003122414546931$

Castilla, E. J. (2008). Gender, Race, and Meritocracy in Organizational Careers. American Journal of Sociology, 113(6), 1479-1526.

Castilla, E. J., \& Benard, S. (2010). The Paradox of Meritocracy in Organizations. Administrative Science Quarterly, 55(4), 543-676.

Centeno, M. A., \& Cohen, J. N. (2012). The Arc of Neoliberalism. Annual Review of Sociology, 38(1), 317-340. doi:10.1146/annurev-soc-081309-150235

Choi, I., Nisbett, R. E., \& Norenzayan, A. (1999). Causal attribution across cultures: Variation and universality. Psychological Bulletin, 125(1), 47-63. doi:10.1037/0033-2909.125.1.47 
Croll, P. R. (2013). Explanations for racial disadvantage and racial advantage: beliefs about both sides of inequality in America. Ethnic and Racial Studies, 36(1), 47-74. doi:10.1080/01419870.2011.632426

Davis, K., \& Moore, W. E. (1945). Some principles of stratification. American Sociological Review, 242-249.

De Botton, A. (2005). Status Anxiety. New York: Vintage.

Delhey, J., \& Dragolov, G. (2014). Why Inequality Makes Europeans Less Happy: The Role of Distrust, Status Anxiety, and Perceived Conflict. European Sociological Review, 30(2), 151-165. doi:10.1093/esr/jct033

Dench, G. (2006). The Rise and Rise of Meritocracy. New York: Wiley-Blackwell.

Deutsch, M. (1985). Distributive Justice: A Social-psychological Perspective. New Haven, CT: Yale University Press.

Dillon, S. (2010, December 7). In PISA Test, Top Scores From Shanghai Stun Experts. The New York Times.

Dobbin, F. (2009). Inventing Equal Opportunity. Princeton, NJ: Princeton University Press.

Durkheim, É. (1912). The Elementary Forms of the Religious Life. London: Courier Dover Publications.

Eccles, J. S., \& Wigfield, A. (2002). Motivational Beliefs, Values, and Goals. Annual Review of Psychology, 53(1), 109-132.

Elias, N. (1939). The Civilizing Process: The history of manners. Oxford: Blackwell Publishing. Espenshade, T. J., \& Radford, A. W. (2009). No Longer Separate, Not Yet Equal: Race and Class in Elite College Admission and Campus Life. Princeton, NJ: Princeton University Press. 
Fischer, C. S., Hout, M., Sanchez Jankowski, M., Lucas, S. R., Swidler, A., \& Voss, K. (1996). Inequality by Design: Cracking the Bell Curve Myth. Princeton, NJ: Princeton University Press.

Goldthorpe, J. H. (1996). Problems of “meritocracy.” In R. Erikson \& J. O. Jonsson, Can Education Be Equalized?. Boulder, CO: Westview Press.

Goldthorpe, J. H., \& Jackson, M. (2008). Education-Based Meritocracy: The Barriers to its Realization. In A. Lareau \& D. Conley, Social Class. How Does it Work? (pp. 118-151). New York: Russell Sage Foundation.

Grayman, J. K., \& Godfrey, E. B. (2013). Social Justice Attitudes and Their Demographic Correlates Among a Nationally Representative Sample of U.S. Adolescents. Social Justice Research, 26(4), 422-444.

Halvorsen, A. T., \& Neary, T. (2001). Building Inclusive Schools: Tools and Strategies for Success. Boston, MA: Allyn and Bacon.

Harris, A. L. (2008). Optimism in the Face of Despair: Black-White Differences in Beliefs About School as a Means for Upward Social Mobility. Social Science Quarterly, 89(3), 608630.

Hayek, F. A. (1960). The Constitution of Liberty. Chicago, IL: University of Chicago Press.

Heine, S. J., \& Buchtel, E. E. (2009). Personality: The Universal and the Culturally Specific. Annual Review of Psychology, 60(1), 369-394. doi:10.1146/annurev.psych.60.110707.163655

Hochschild, J. L. (1996). Facing Up to the American Dream: Race, Class, and the Soul of the Nation. Princeton, NJ: Princeton University Press. 
Hoxby, C. M., \& Avery, C. (2013). Low-Income High-Achieving Students Miss Out on Attending Selective Colleges. New York: Brookings Papers on Economic Activity.

Huber, J., \& Form, W. H. (1973). Income and ideology: an analysis of the American political formula. Free Press.

Hunt, M. O. (2007). African American, Hispanic, and White Beliefs about Black/White Inequality, 1977-2004. American Sociological Review, 72(3), 390-415. doi:10.1177/000312240707200304

ISSP Research Group. (2012). International Social Survey Programme 2009: Social Inequality IV (ISSP 2009). Cologne: GESIS Data Archive.

Jackson, M. (Ed.). (2013). Determined to Succeed? Performance versus Choice in Educational Attainment. Stanford, CA: Stanford University Press.

Jackson, M., Erikson, R., Goldthorpe, J. H., \& Yaish, M. (2007). Primary and Secondary Effects in Class Differentials in Educational Attainment The Transition to A-Level Courses in England and Wales. Acta Sociologica, 50(3), 211-229.

Jost, J. T., \& Banaji, M. R. (1994). The role of stereotyping in system-justification and the production of false consciousness. British Journal of Social Psychology, 33(1), 1-27. doi:10.1111/j.2044-8309.1994.tb01008.x

Jost, J. T., Banaji, M. R., \& Nosek, B. A. (2004). A Decade of System Justification Theory: Accumulated Evidence of Conscious and Unconscious Bolstering of the Status Quo. Political Psychology, 25(6), 881-919. doi:10.1111/j.1467-9221.2004.00402.x

Kalmijn, M., \& Kraaykamp, G. (2003). Dropout and Downward Mobility in the Educational Career: An Event-History Anaylsis of Ethnic Schooling Differences in the Netherlands. Educational Research and Evaluation, 9(3), 265-287. 
Karabel, J. (2005). The Chosen: The Hidden History of Admission and Exclusion at Harvard, Yale, and Princeton. Boston, MA: Houghton Mifflin Harcourt.

Kay, A. C., Gaucher, D., Peach, J. M., Laurin, K., Friesen, J., Zanna, M. P., \& Spencer, S. J. (2009). Inequality, discrimination, and the power of the status quo: Direct evidence for a motivation to see the way things are as the way they should be. Journal of Personality and Social Psychology, 97(3), 421-434. doi:10.1037/a0015997

Khan, S. R. (2010). Privilege: The Making of an Adolescent Elite at St. Paul's School. Princeton, NJ: Princeton University Press.

Kloosterman, R., Ruiter, S., De Graaf, P. M., \& Kraaykamp, G. (2009). Parental education, children's performance and the transition to higher secondary education: trends in primary and secondary effects over five Dutch school cohorts (1965-99). The British Journal of Sociology, 60(2), 377-398.

Kluegel, J. R., \& Smith, E. R. (1986). Beliefs About Inequality: Americans' Views of What Is and What Ought to Be. New York: Transaction Publishers.

Lamont, M., Beljean, S., \& Clair, M. (2014). What is missing? Cultural processes and causal pathways to inequality. Socio-Economic Review, 12(3), 573-608. doi:10.1093/ser/mwu011

Lareau, A. (2000). Home Advantage: Social Class and Parental Intervention in Elementary Education. Oxford: Rowman \& Littlefield.

Lareau, A. (2011). Unequal Childhoods: Class, Race, and Family Life, Second Edition with an Update a Decade Later. University of California Press.

Lerner, M. J. (1980). The Belief in a Just World. A Fundamental Delusion. New York: Plenum Press. 
LeTendre, G. K., Hofer, B. K., \& Shimizu, H. (2003). What Is Tracking? Cultural Expectations in the United States, Germany, and Japan. American Educational Research Journal, $40(1), 43-89$.

Liu, A. (2011). Unraveling the myth of meritocracy within the context of US. Higher Education, 62(4), 383-397. doi:10.1007/s10734-010-9394-7

Lucas, S. R. (2001). Effectively Maintained Inequality: Education Transitions, Track Mobility, and Social Background Effects. American Journal of Sociology, 106(6), 1642-1690.

McCall, L. (2013). The Undeserving Rich. American Beliefs about Inequality, Opportunity, and Redistribution. New York: Cambridge University Press.

McCoy, S. K., \& Major, B. (2007). Priming meritocracy and the psychological justification of inequality. Journal of Experimental Social Psychology, 43(3), 341-351. doi:10.1016/j.jesp.2006.04.009

McCoy, S. K., Wellman, J. D., Cosley, B., Saslow, L., \& Epel, E. (2013). Is the belief in meritocracy palliative for members of low status groups? Evidence for a benefit for selfesteem and physical health via perceived control. European Journal of Social Psychology, 43(4), 307-318. doi:10.1002/ejsp.1959

Meyer, J. W., \& Rowan, B. (1977). Institutionalized Organizations: Formal Structure as Myth and Ceremony. American Journal of Sociology, 83(2), 340-363.

Michaels, W. B. (2006). The Trouble with Diversity: How We Learned to Love Identity and Ignore Inequality. New York: Macmillan.

Miller, D. (1999). Principles of Social Justice. Cambridge, MA: Harvard University Press. Mills, C. W. (1959). The Sociological Imagination. London: Oxford University Press. 
Mincer, J. (1958). Investment in Human Capital and Personal Income Distribution. Journal of Political Economy, 66.

Noguera, P. A., \& Wing, J. Y. (2008). Unfinished Business: Closing the Racial Achievement Gap in Our Schools. San Francisco, CA: Wiley.

Nozick, R. (1974). Anarchy, State, and Utopia. New York: Basic Books.

Oakes, J. (2005). Keeping Track: How Schools Structure Inequality. New Haven, CT: Yale University Press.

O’Connor, C. (1999). Race, class, and gender in America: narratives of opportunity among lowincome African American youths. Sociology of Education, (3), 72.

Panayotakis, C. (2014). Capitalism, Meritocracy, and Social Stratification: A Radical Reformulation of the Davis-Moore Thesis. American Journal of Economics and Sociology, 73(1), 126-150. doi:10.1111/ajes.12068

Prentice, D. A., \& Carranza, E. (2002). What Women and Men Should Be, Shouldn't Be, Are Allowed to Be, and Don't Have to Be: The Contents of Prescriptive Gender Stereotypes. Psychology of Women Quarterly, 26(4), 269-281. doi:10.1111/1471-6402.t01-1-00066

Raftery, A. E., \& Hout, M. (1993). Maximally Maintained Inequality: Expansion, Reform, and Opportunity in Irish Education, 1921-75. Sociology of Education, 66(1), 41-62. doi:10.2307/2112784

Rawls, J. (1971). A Theory of Justice. Cambridge, MA: Harvard University Press.

Rhoads, R. A., Saenz, V., \& Carducci, R. (2005). Higher Education Reform as a Social Movement: The Case of Affirmative Action. The Review of Higher Education, 28(2), 191-220. doi:10.1353/rhe.2004.0039 
Rizvi, F. (2013). Equity and marketisation: a brief commentary. Discourse: Studies in the Cultural Politics of Education, 34(2), 274-278. doi:10.1080/01596306.2013.770252

Saunders, P. (2006). Meritocracy and Popular Legitimacy. The Political Quarterly, 77, 183-194. doi:10.1111/j.1467-923X.2006.00794.X

Savage, G. C., Sellar, S., \& Gorur, R. (2013). Equity and marketisation: emerging policies and practices in Australian education. Discourse: Studies in the Cultural Politics of Education, 34(2), 161-169. doi:10.1080/01596306.2013.770244

Sen, A. (2000). Merit and Justice. In K. J. Arrow, S. Bowles, \& S. Durlauf (Eds.), Meritocracy and Economic Inequality (pp. 5-16). Princeton, NJ: Princeton University Press.

Shepelak, N. J. (1989). Ideological stratification: American beliefs about economic justice. Social Justice Research, 3(3), 217-231.

Smith, A. (1776). An Inquiry Into the Nature and Causes of the Wealth of Nations. London: Methuen \& Co.

Smith, M. L., \& Matějů, P. (2012). Two Decades of Value Change: The Crystallization of Meritocratic and Egalitarian Beliefs in the Czech Republic. Social Justice Research, 25(4), 421-439. doi:10.1007/s11211-012-0164-9

Steele, C. M. (2011). Whistling Vivaldi: How Stereotypes Affect Us and What We Can Do (Issues of Our Time). W. W. Norton \& Company.

Stephens, N. M., Markus, H. R., \& Phillips, L. T. (2014). Social Class Culture Cycles: How Three Gateway Contexts Shape Selves and Fuel Inequality. Annual Review of Psychology, 65(1), 611-634. doi:10.1146/annurev-psych-010213-115143

Stevens, M. L. (2007). Creating a Class. College Admissions and the Education of Elites. Cambridge, MA: Harvard University Press. 
Stevenson, H., \& Stigler, J. W. (1994). Learning Gap: Why Our Schools Are Failing And What We Can Learn From Japanese And Chinese Educ. Simon and Schuster.

Telles, E., \& Bailey, S. (2013). Understanding Latin American Beliefs about Racial Inequality. American Journal of Sociology, 118(6), 1559-1595. doi:10.1086/670268

Tsay, A., Lamont, M., Abbott, A., \& Guetzkow, J. (2003). From character to intellect: changing conceptions of merit in the social sciences and humanities, 1951-1971. Poetics, 31(1), 23-49. doi:10.1016/S0304-422X(03)00002-0

Van de Werfhorst, H. G., \& Mijs, J. J. B. (2010). Achievement inequality and the institutional structure of educational systems: A comparative perspective. Annual Review of Sociology, 36, 407-428.

Walton, G. M., Spencer, S. J., \& Erman, S. (2013). Affirmative Meritocracy. Social Issues and Policy Review, 7(1), 1-35. doi:10.1111/j.1751-2409.2012.01041.x

Walzer, M. (1983). Spheres of Justice: a Defense of Pluralism and Equality. Basic Books.

Weiner, B. (1972). Human Motivation. New Jersey, NJ: Psychology Press.

Willetts, D. (2006). The Future of Meritocracy. In G. Dench, The Rise and Rise of Meritocracy. Malden, MA: Blackwell Publishing.

Yair, G. (2007). Meritocracy. In G. Ritzer (Ed.), The Blackwell Encyclopedia of Sociology (pp. 2954-58). Oxford: Blackwell Publishing.

Yair, G. (2008). The Last Musketeer of the French Revolution: Exploring the Republican Political Agenda of Pierre Bourdieu. The Open Sociology Journal, 1(1), 23-35.

Young, M. (1958). The Rise of the Meritocracy. New York: Transaction Publishers.

Young, M. (1994). Meritocracy revisited. Society, 31(6), 87-89. 
Young, M. (2001, June 28). Down with Meritocracy: The Man Who Coined The Word Four Decades Ago Wishes Tony Blair Would Stop Using It. The Guardian. 
TABLES \& FIGURES

Meritocratic traits

\begin{tabular}{|c|c|}
\hline Manliness, aggression, asceticism, (bi)sexuality & ${\text { Sparta, } 400 \text { B.C. }^{\mathrm{a}}}$ \\
\hline Pacifism, vegetarianism, asceticism, asexuality & Western Europe, 479-1096 a \\
\hline Religiosity, honor, braveness & \begin{tabular}{|l} 
Western Europe, 1096-1500 a \\
\end{tabular} \\
\hline Dancing skills, elegance, worldliness & England, $1750-1890^{a}$ \\
\hline Silence, composure, hunting skills & Brazil, 1600-1960 a \\
\hline Creativity, intelligence, stamina & The West, today ${ }^{a}$ \\
\hline Passion, resoluteness, violence, forwardness & Western Europe, $1300-1600^{\mathrm{b}}$ \\
\hline $\begin{array}{l}\text { Self-discipline, self-restraint, emotional control, } \\
\text { cunning }\end{array}$ & Western Europe, $1600-1800^{\mathrm{b}}$ \\
\hline Race (white), gender (male), intelligence & American Ivy League universities, $1900-1920^{\mathrm{c}}$ \\
\hline $\begin{array}{l}\text { Race (white), gender (male), pedigree, character, } \\
\text { leadership, intelligence }\end{array}$ & American Ivy League universities, $1920-1950^{\mathrm{c}}$ \\
\hline Athleticism, life experience, intelligence & American Ivy League universities, $1950-2005^{\mathrm{c}}$ \\
\hline $\begin{array}{l}\text { Intellect, technical skills, sociability, morality, } \\
\text { personality }\end{array}$ & American academia, $1951-1955^{\mathrm{d}}$ \\
\hline Intellect, technical skills & American academia, $1967-1971^{\mathrm{d}}$ \\
\hline Sensitivity, friendliness, cooperativeness, loyalty & American women, today ${ }^{\mathrm{e}}$ \\
\hline $\begin{array}{l}\text { Assertiveness, forcefulness, competitiveness, } \\
\text { self-reliance }\end{array}$ & American men, today ${ }^{\mathrm{e}}$ \\
\hline
\end{tabular}

Table 1. A selection of meritocratic traits throughout history. Sources: De Botton, 2008, pp. 175-179; Elias, 1939; Karabel, 2005; Prentice \& Carranza, 2002; Tsay, Lamont, Abbott, \& Guetzkow, 2003. Note: $\mathrm{a}=$ De Botton; $\mathrm{b}=$ Elias; $\mathrm{c}=$ Karabel; $\mathrm{d}=$ Tsay et al.; $\mathrm{e}=$ Prentice $\&$ Carranza. 


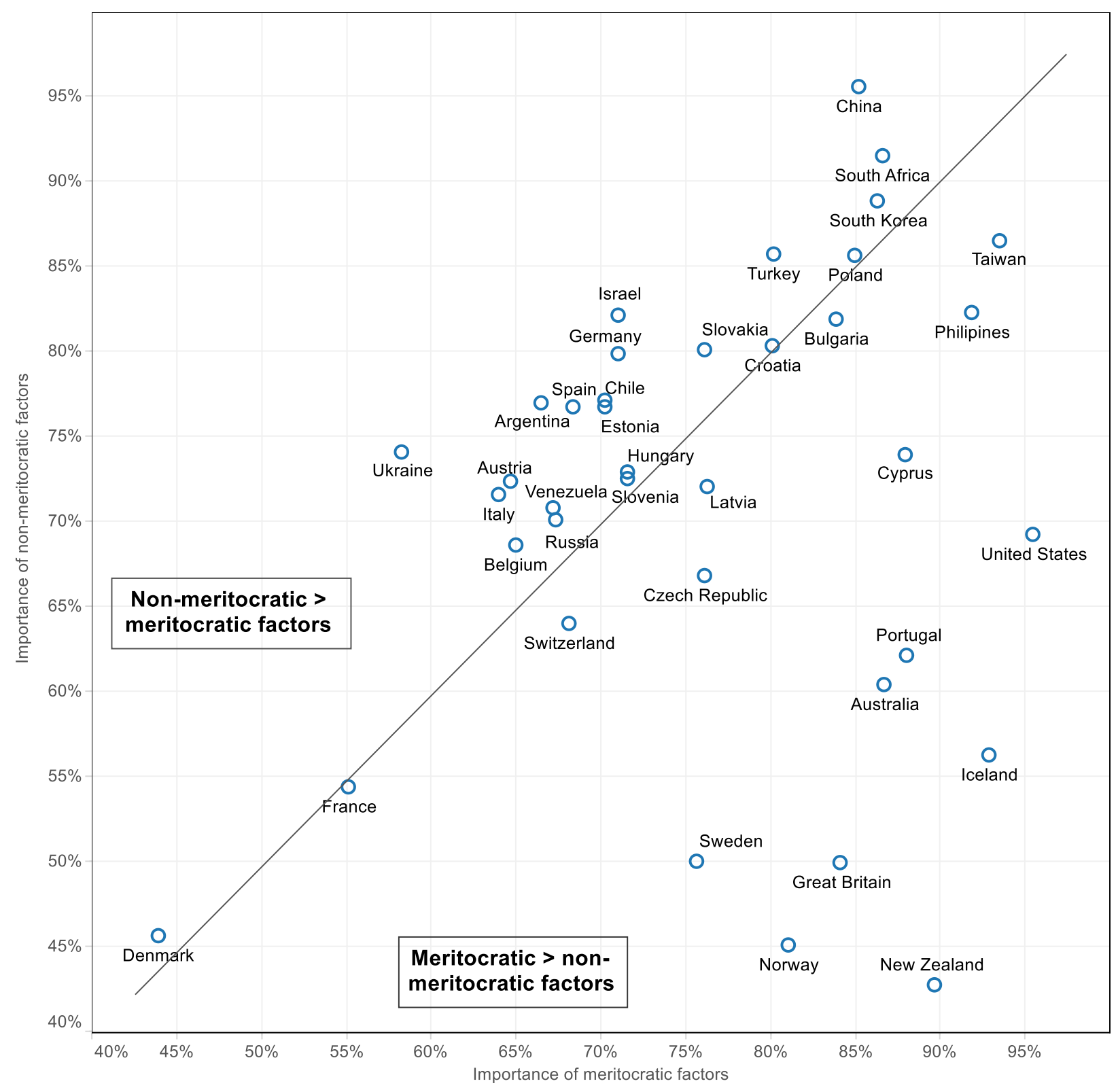

Figure 1. Meritocratic and non-meritocratic beliefs around the world. Note: Countries are plotted by the percentage of citizens who think that meritocratic factors (e.g., hard work, ambition) are essential to societal success (x-axis) and the percentage of citizens who hold that one or more non-meritocratic factors (e.g., family background, gender or race) are essential to societal success (y-axis). Citizens of countries below the diagonal hold meritocratic beliefs to a (much) stronger extent than non-meritocratic beliefs, while the inverse is true for citizens of countries above the diagonal. Source: ISSP Research Group (2012). 